\title{
Cybersecurity Law for Consumer Online Vaccine Sales
}

\author{
Daradri Yaunita
}

Universitas Pembangunan Nasional Veteran Jakarta, Indonesia

\begin{abstract}
The development of information technology in the world has progressed so rapidly to get information, insights, products and needs in everyday life through the internet, everyone from all over the world accesses the site to conduct transactions online. Buying and selling opportunities using e-commerce/online buying and selling media which is a liaison between business actors and consumers, so that the agreement or agreement made is through online. Vaccines are biological elements that have certain characteristics and require special handling in the vaccine chain since they are produced at the factory until they are used in service units. Deviations from existing provisions can result in damage to the vaccine thereby reducing or even eliminating the potential that can lead to nonimmunity. The vaccine cold chain is a procedure used to keep the vaccine at a certain temperature that has been set so that it still has good potential starting from the manufacture of the vaccine to the time of administration. based on Law Number 19 of 2016 concerning Amendments to Law Number 11 of 2008 concerning Information and Electronic Transactions and Law No. 36 of 2009 concerning Health, Regulation of the Food and Drug Supervisory Agency Number 24 of 2021 concerning Supervision of Management of Drugs, Drug Ingredients, Narcotics, Psychotropics and Pharmacy Precursors in Pharmaceutical Service Facilities.
\end{abstract}

Keywords: Consumer Protection, Online Vaccines and Cold Chain

\section{Introduction}

The development of information technology in the world is progressing so rapidly that it causes social, economic and cultural changes. This condition causes distance is not an obstacle in the business world. The striking development of internet technology makes a product can be marketed globally on a website, so that everyone can directly access the site to conduct online transactions. Online buying and selling activities or what is called E-commerce are transaction activities that use electronic media as a liaison between business actors and consumers, so that agreements or agreements made are through online. The opportunity to buy and sell using e-commerce media or known as online buying and selling in Indonesia itself also experiences positive and negative impacts, one of which causes legal problems related to the delivery of information and/or electronic transactions. However, with buying and selling activities carried out online using electronic transaction media, misunderstandings often occur between business actors and consumers. Legal protection for consumers is regulated in Law Number 8 of 1999 concerning Consumer Protection. This law is expected to guarantee legal certainty for consumers in e-commerce transactions.The first legal protection that can be done by the government is by listening to the aspirations or objections expressed by the public regarding the sale of illegal drugs online so that regulations can be formed regarding these problems in accordance with the rights of the community as consumers. If these regulations are not implemented, both by the public as consumers and business actors, then the next legal protection that can be carried out by the government against this problem is law enforcement through the general courts in Indonesia. Vaccines are biological elements that have certain characteristics and require special handling in the vaccine chain since they are produced in the factory until they are used in service units. Deviations from existing regulations can result in damage to the vaccine thereby reducing or even eliminating the potential that can lead to non-immunity. Monitoring the temperature of vaccine storage is very important in determining quickly whether the vaccine is still suitable for use or not. The existence of various tools with very sensitive indicators such as Thermometer, Vaccine Vial Monitor (VVM), Freeze-tag is very helpful in monitoring the storage temperature and delivery of vaccines. The success of the immunization program cannot be separated from the availability of a vaccine chain to vaccine recipients so that they can maintain and guarantee the quality of the vaccines given. With a vaccine chain with good quality standards, the quality of the vaccines given will be maintained. The vaccine chain consists of freezing to store vaccines, and vaccine carriers to bring vaccines to immunization services, especially for activities outside the building/field. Vaccine storage requires special attention because vaccines are biological preparations that are susceptible to changes in environmental temperature. In the Regulation of the Minister of Health Number 12 of 2017 concerning the Implementation of Immunization, it is stated that vaccines are biological products that are easily damaged so they must be stored at a certain temperature, namely at a temperature of 2 to $8^{\circ} \mathrm{C}$ for vaccines that are sensitive to freezing. (not frozen), and at 15 to -25 . C for heat sensitive vaccines. Currently, only polio vaccine still requires storage at temperatures below $0^{\circ} \mathrm{C}$. A number of vaccines, such as Hepatitis B, DPT-HBHib, IPV, DT, Td will potentially be damaged if exposed to freezing temperatures. Meanwhile, the Polio, BCG, and Measles vaccines will potentially be damaged if exposed to hot temperatures. But in general, vaccines will be damaged if exposed to direct sunlight. Vaccine classification can be divided into two groups, namely, the first is based on antigen classification of vaccines. both classifications based on sensitivity to temperature Research conducted by McGuire in 2006 in Pakistan showed that out of 90 samples of vaccine shipments, $60 \%$ of vaccines were exposed to freezing temperatures when transported by the postal service. The path of UNICEF in 2005 monitoring the temperature of the cold chain in Bolivia shows freezing 
occurs at almost every level of every cold chain distribution system, especially during refrigerated storage, $60 \%$ of the 25 samples freeze, and also during transportation, of the samples. 11 vaccine shipments were $100 \%$ frozen.Vaccine cold chain is a procedure used to keep the vaccine at a certain temperature that has been set so that it still has good potential from the manufacture of the vaccine to the time of its administration (injected or dripped) to the target. Cold chain products have a short shelf life, complex storage, handling and distribution systems with multiple requirements, high shipping costs, and the need for a controlled cold environment temperature. Pharmaceutical wholesalers who distribute cold chain products must be able to ensure that products are maintained at a temperature that can be maintained throughout the process of receiving, storing, and delivering them to the user's hands to avoid unwanted risks. The procedure for receiving the product from the principal must meet the requirements for a Good Drug Distribution Method. Pharmaceutical wholesalers must check: product name, product physical condition, product quantity, expiry date, batch number, condition of temperature monitor and condition of Vaccine Vial Monitor specifically for vaccines equipped with VVM. If the condition of the temperature monitoring device shows temperature deviations and or the VVM condition is close to the usable limit at the time of receipt, the deviation is reported and the product is stored in a temperature storage area according to a special label. The product passed the inspection and was in good condition upon receipt and placed in appropriate temperature storage. According to CDOB (BPOM, 2012) there are two storage temperatures at pharmaceutical wholesalers (PBF) facilities, namely: $\mathrm{s}$

1) Chiller atau cold room (temperature $2^{\circ} \mathrm{c} s / \mathrm{d} 8^{\circ} \mathrm{c}$ ), to store vaccines and serum at storage temperature $2^{\circ} \mathrm{c} s / \mathrm{d}$ $8^{\circ} \mathrm{c}$, usually used for measles vaccine storage, BCG, DPT, TT, DT, Hepatitis B, DPT-HB

2) Freezer atau freezer room (suhu $-15^{\circ} \mathrm{c} \quad \mathrm{s} / \mathrm{d}-25^{\circ} \mathrm{c}$ ) for storing frozen products for example polio vaccine.

Chiller and freezer able to maintain the required temperature. A calibrated thermometer is placed at the most accurate and representative point, this is necessary to continuously monitor the temperature during operation. An accurate and representative temperature point of the entire storage area is determined by mapping the critical point temperature. The temperature in cold chain product storage is monitored at least 3 (three) times a day and for vaccine storage it is recommended to be at a temperature of $2.5-7.5$ ${ }^{\circ} \mathrm{C}$, for vaccine storage $2-8{ }^{\circ} \mathrm{C}$, the alarm must be checked periodically to ensure the alarm is functioning well. good (BPOM, 2015) Monitoring of vaccine storage temperature is very important in determining quickly whether the vaccine is still suitable for use or not. The existence of various tools with very sensitive indicators such as Thermometer, Vaccine Vial Monitor (VVM), Freeze-tag is very helpful in monitoring the storage temperature and delivery of vaccines. For vaccines that have a VVM indicator, the color of the VVM must be monitored. Freeze tag is a tool used to monitor vaccines against exposure to freezing temperatures. This tool uses an electronic system by displaying a grass sign (V) or a cross (X). If the grass mark on the monitor changes to a cross, it indicates that the vaccine has been exposed to temperatures below $-0^{\circ} \mathrm{C}$ for more than 1 hour. stored or distributed until used in the service. The VVM is attached to the vaccine vial.

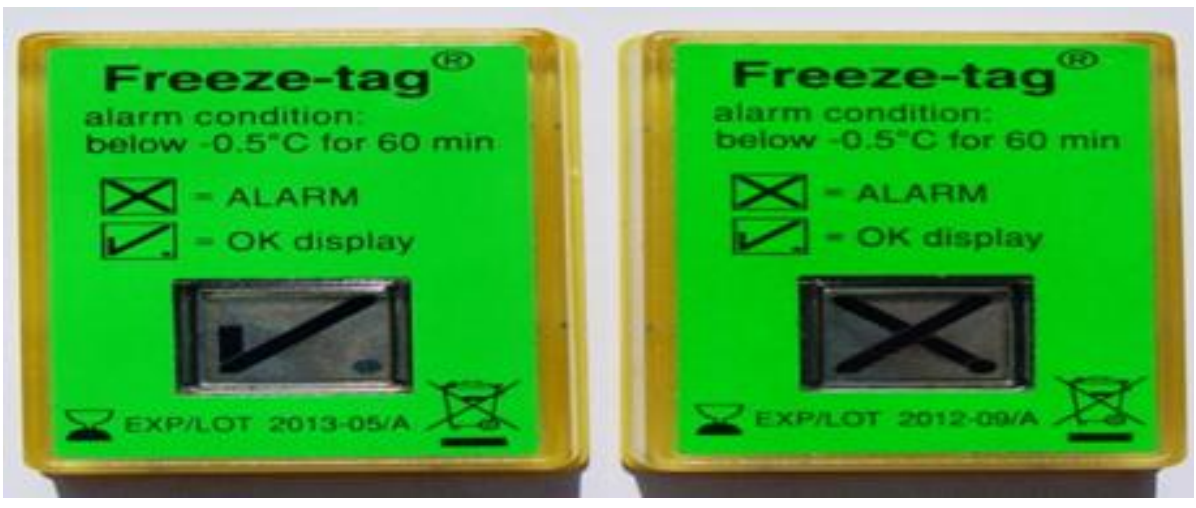

Picture 1: Freeze-Tag

\section{Research Method}

This research is based on a normative approach that does not require a population and sample, with a normative juridical approach referring to legal norms, because this type of research emphasizes the aspect of understanding a legal norm contained in legislation and norms that live and develop in society. In research or study of normative legal science, activities to explain the law do not require data support or social facts, because normative legal science does not recognize social data or facts, only legal materials are known. So to explain the law or to find meaning and give value to the law, only legal concepts are used and the steps taken are normative steps. Pendekatan penelitian adalah metode atau cara mengadakan penelitian. This study uses a statutory approach, namely legal research carried out by examining library materials or secondary data as the basic material for research by conducting a search on regulations and literature related to the problems studied. The author will conduct a study and review of the Legal Protection for Consumers for Online Vaccine Sales. The nature of the research used by the author is the nature of descriptive analytical research. According to Zainudin Ali, descriptive analytical research is research that discloses laws and regulations relating to legal theories that are the object of research. Metode analisis data yang digunakan dalam 
penulisan karya ilmiah ini adalah analisis deskriptif kualitatif dimana bahan hukum sekunder yang berasal dari hasil penelitian kepustakaan kemudian dipilih dan disusun secara sistematis untuk mendapatkan data yang relevan yang kemudian dapat digunakan untuk menjawab rumusan masalah yang disampaikan. Sistematika atau runtutan analisis deskriptif kualitatif dalam penggunaannya tidak ada suatu pedoman yang jelas, akan tetapi pada prinsipnya setiap item dari permasalahan yang diajukan harus terjawab dalam analisis data dengan mengkaitkan satu sama lain atau dengan kata lain terdapat hubungan timbal-balik. Analisis dan pendekatan terhadap undang-undang, teori dan asas hukum, putusan mahkamah konstitusi dan yurisprudensi adalah langkah yang dilakukan penulis untuk menjawab rumusan masalah tentang Perlindungan Hukum Bagi Konsumen Atas Penjualan Vaksin Secara Online.

\section{Discussion}

The activity of selling Infanrix Vaccines Online through Flatfoam E-commerce, where online buying and selling activities result in the position of consumers and business actors being unbalanced and consumers being in a weak position. Consumers are used as objects of business activity by business actors in order to obtain the maximum profit. The main factor that becomes the weakness of consumers is the level of consumer awareness of their rights is still low, every citizen has the right to legal protection that is mandatory by the state. One of the protections that must be provided by the state for consumers is consumer protection. The purpose of consumer protection is so that people do not consume or use goods and or services that can endanger safety, health and so on, so that people feel safe and get satisfaction. In addition, if a consumer buys or consumes a product, then the consumer may get a loss or injury due to product defects, including damage to the product or other goods and economic losses. Welfare development efforts to make people healthy in the past were still the main focus on curative efforts that put more emphasis on treatment. However, over time the government realized that disease was one of the inhibiting factors for development. Many cases of disease have had a serious impact on the amount of costs incurred for treatment, so that government programs are finally prioritized on preventive measures or gradual prevention. One of the government programs for the Indonesian people is immunization, which of course must be accompanied by massive counseling and outreach to the community. The term consumer protection relates to legal protection. Therefore, consumer protection contains a legal aspect. Some things about consumers who get protection are not just physical protection, but also abstract consumer rights. Consumer protection is actually identical to the protection provided by law regarding consumer rights. In general, it is known that there are 4 (four) basic consumer rights recognized internationally by John F. Kennedy, namely:

1) The right to security (the right to safety);

2) The right to be informed;

3) The right to choose (the right to choose);

4) The right to be heard

In Law Number 8 of 1999 concerning Consumer Protection, hereinafter referred to as UUPK, it has been stated explicitly in a clause concerning the responsibilities that must be given by business actors to consumers. In UUPK Article 19 paragraph (1) it is stated that "Business actors are responsible for providing compensation for damage, pollution, and/or consumer losses due to consuming goods and/or services produced or traded." Infanrix vaccine is an injection preparation containing diphtheria toxoid, tetanus toxoid, pertussis toxoid, Haemagglutinin filament, Pertactin, Antigen (substance that stimulates the immune response that produces antibodies), this drug is produced by Smith Kline Beecham Pharmaceutical. Infanrix vaccine is indicated as a primary and additional vaccination in infants against DPT, hepatitis B, poliomyelitis. Vaccination or immunization is a process in the body so that a person has immunity against a disease. Primary vaccination schedule consists of two or three doses $(0.5 \mathrm{ml})$. Infarix Vaccine belongs to the Hard Drugs class, is injected intramuscularly (directly through a vein), therefore the use of this drug must be carried out by professional medical personnel and a doctor's prescription. Information on the Infanrix Vaccine, namely:

Golongan: Obat Keras.

1) Kelas Terapi: Vaksin, Antisera dan Imunologi.

2) Kandungan: Adsorbed diptheria toxoid not, adsorbed tetanus toxoid not, adsorbed pertusis toxoid $25 \mathrm{mcg}$, adsorbed filamentous haemagglutinin $25 \mathrm{mcg}$, adsorbed pertactin $8 \mathrm{mcg}$, adsorbed recombinant HBsAg $10 \mathrm{mcg}$, 40 D-antigen units of type 1 (Mahoney), 8 D-antigen units of type 2 (MEF-1) dan 32 D-antigen units of type 3 (Saukett) of the poliovirus, Dsorbed polysaccharide of $\mathrm{HiB}$ (PRP) $10 \mathrm{mcg}$ (conjugated to tetanus toxoid 20-40 $\mathrm{mcg})$.

3) Shape: Injection Liquid.

4) Sales Unit: Dus.

5) Packaging: Box, 1 Prefilled Syringe $0.5 \mathrm{~mL}+1$ Vial 0.5 $\mathrm{mL}$.

6) Pharmacy: Smith Kline Beecham Pharmaceutical.

Injeksi Intramuskular (IM) dalam Vaksinasi primer

1) Infants 3 months 1 or 2 doses, with an interval of at least 1 month between primary doses.

2) Additional doses may be given at least 6 months after the last priming dose and usually between 11 and 13 months of age ( 2 doses)

3) Dosage before the age of 18 months (3 doses).

4) Babies born prematurely at least 24 weeks, gestation 3 doses half-life (interval) of at least 1 month between primary doses.

5) A booster dose can be given at least 6 months after the last primary dose and beyond 18 months of age.Efek Samping

Vaksin Infanrix:

1) Loss of appetite

2) Irritable, restless, tired.

3) Pain

4) Redness

5) Local swelling at the injection site $(\leq 50 \mathrm{~mm})$

6) Fever $38^{\circ} \mathrm{C}$

7) Nervous

8) Digestive disorders: vomiting, diarrhea.

9) Pruritus (itching)

10) Contraindications 
Avoid using Infanrix Vaccine in patients who have indications:

1) Hypersensitivity to vaccines or after previous administration of DPT, hepatitis B, polio or HIB.

2) Encephalopathy (brain disorder) of unknown etiology, occurring within 7 days after the previous vaccination.

Drug Interactions The following are some drug interactions that commonly occur when using Infanrix Hexa Vaccine:

1) Respons yang mungkin tidak tercapai pada pasien yang menerima imunosupresan.

2) Vaksin co-administrasi bersama konjugat pneumokokus dapat meningkatkan tingkat reaksi demam.

Online Vaccine Sellers have an obligation to deliver goods or services as good and safe as possible and strive to provide satisfaction to consumers. Providing correct information about a product is also very important. This will relate to security, health and consumer safety issues. Consumer protection is an integral part of sound business activities. In a healthy business activity there is a balance of legal protection between consumers and sellers. The absence of a balanced protection leaves consumers in a weak position. Losses experienced by consumers can arise as a result of unlawful acts committed by online vaccine sellers. In UUPK formulated rules regarding the rights and obligations of consumers and online vaccine rights as business actors. The types of obligations of online vaccine sellers listed in Article 7 of the UUPK regulate the product obligations of online vaccine sellers. Consumer protection means questioning the guarantee or certainty regarding the fulfillment of the protection provided to the community as consumers, in this case consumers who consume certain types of food or drug products explain that consumer rights include:

1) The right to comfort, security and safety in consuming goods and/or services; the right to choose the goods and/or services and to obtain the goods and/or services in accordance with the exchange rate and the promised conditions and guarantees;

2) The right to correct, clear, and honest information regarding the condition and guarantee of goods and/or services;

3) The right to have their opinions and complaints heard on the goods and/or services used;

4) The right to obtain proper advocacy, protection, and efforts to resolve consumer protection disputes;

5) The right to receive consumer guidance and education;

6) The right to be treated or served correctly and honestly and not discriminatory;

7) The right to obtain compensation, compensation and/or replacement, if the goods and/or services received are not in accordance with the agreement or not properly;

8) Rights regulated in the provisions of other laws and regulations.

Legal protection by the POM is very important for consumers because the public is often given wrong information by business actors. According to Satjipto Raharjo, legal protection is to provide protection for human rights that are harmed by others and this protection is given to the community so that they can enjoy all the rights granted by law. Legal protection for consumers is to protect consumer rights. Although very diverse, broadly speaking, consumer rights can be divided into three rights which are the basic principles, namely:

a) Hak yang dimaksudkan untuk mencegah konsumen dari kerugian, baik kerugian personal, maupun kerugian harta kekayaan;

b) Hak untuk memperoleh barang dan/atau jasa dengan harga wajar;

c) Hak untuk memperoleh penyelesaian yang patut terhadap permasalahan yang dihadapi.

If consumers really want to be protected, then consumer rights must be fulfilled, both by the state and business actors, because the fulfillment of consumer rights will protect consumers' losses from various aspects. In Article 2 of the UUPK, it is stated that legal protection for consumers is carried out as a joint effort based on five principles in national development, namely the principle of benefit, the principle of justice, the principle of balance, the principle of security and safety, and the principle of legal certainty. Through these five principles there is a commitment to realize several objectives of legal protection for consumers which have been regulated in Article 3 of the UUPK. To realize the goal of legal protection for consumers, the state is responsible for fostering and implementing legal protection for consumers. The development and implementation of legal protection for consumers is carried out through the following efforts:

a) Creating a business climate and growing healthy relationships between business actors and consumers;

b) The development of legal protection institutions for consumers, either by the state or by non-governmental organizations;

c) Increasing the quality of human resources as well as increasing research and development activities in the field of legal protection for consumers.

The purpose of the planned implementation, development and regulation of legal protection for consumers is to increase the dignity and awareness of consumers, and indirectly encourage business actors to carry out business activities with a full sense of responsibility. Business actors realize that they must respect consumer rights, produce quality goods and services, safe to use, follow applicable standards, at appropriate prices. The existence of a legal relationship in the form of an agreement is of course very helpful in strengthening the position of consumers in dealing with parties that harm their rights. The legal consequences of a contract are basically born from the existence of a legal relationship from an engagement, namely in the form of rights and obligations. Engagement can occur for two reasons, namely because of an agreement and because of the law (Article 1233 of the Civil Code). These two notions greatly affect the protection and resolution of legal disputes involving the interests of consumers in them. Every engagement that causes harm to another person can be held accountable from the perpetrator. With the agreement or agreement resulting in a legal bond for the parties. Generally, the legal ties resulting from the agreement are mutually burdensome or a burden to the parties involved, namely the seller and the buyer. Basically, buying and selling includes an agreement as contained in the Third Book of the Fifth Chapter of the Civil Code. This has resulted in the rights and obligations of the parties in the 
online vaccine sale and purchase agreement. These rights and obligations must be carried out by the parties properly in accordance with the agreement that has occurred. In an engagement due to an agreement, the parties agree to bind themselves to carry out their respective obligations, and for that each obtains his rights. The obligations of the parties are called achievements. In order for the agreement to meet the expectations of both parties, each needs to have the good faith to fulfill his or her accomplishments responsibly. The law here plays a role in ensuring that these obligations are carried out with full responsibility according to the original agreement. If there is a violation of the agreement or what is usually called a default, then the aggrieved party can demand its fulfillment based on the agreement. In addition to the engagement by agreement, another source of engagement is the law. Engagements that arise because of the Act are distinguished in Article 1352 of the Civil Code into:

a) An engagement that is determined by law;

b) Bonds that arise because of the actions of people.

The criteria for the engagement that arise because of this person's actions are:

a) Fulfilling legal provisions, is called an act according to law;

b) Failure to comply with the provisions of the law is called an act against the law.

In relation to consumer protection law, the second category, namely unlawful acts is very important because it is most likely to be used by consumers as a juridical basis for prosecution against the opposing party in the dispute. Acts against the law (onrechtmatige daad) are included in Article 1365 of the Civil Code. Subekti translated the article into, "Every unlawful act that causes harm to another person, obliges the person who because of his mistake to issue the loss, compensates for the loss.""against" is attached to the active nature and the passive nature. Active nature can be seen when intentionally doing something that causes harm to others, so deliberately make a movement so that it is clear that the active nature of the term "against" is clearly visible. On the other hand, if he is deliberately silent or in other words, if he is passive, causing harm to others, then he has "fought" without having to move his body. Mariam Darus Badrulzaman stated that the conditions that must exist to determine an act as an unlawful act are as follows:

a) There must be an action, what is meant by this action is either positive or negative, meaning that every behavior is doing or not doing;

b) act must be against the law;

c) There is a loss;

d) There is a causal relationship between actions against the law with loss;

e) There is an error (schuld).

The word "law" in terms of unlawful acts is not explained in the Act, giving rise to various interpretations. There are interpretations that only see the law narrowly, which is limited to the law, but there are also those who interpret it broadly, namely the law plus elements of decency and propriety. Narrow interpretation involves two main elements of unlawful acts, namely:

a) The element of violation of a person's subjective rights; b) An element of action that is contrary to the legal obligations of the perpetrator.

In this case, analyzing the form of legal protection for consumers who experience losses from selling the Infanrix Vaccine online, based on the UUPK that it turns out that business actors can be said to be acting against the law. According to Mariam Darus Badrulzaman, there are several conditions to determine an act against the law such as there must be an action, the sale of the Infanrix Vaccine online is a seller who is free, unlicensed and does not send vaccines in accordance with the provisions, namely with a cold chain system that is not in accordance with regulations legislation in force in Indonesia and has violated consumer rights contained in the UUPK. The next condition is that there are losses, namely there are material and immaterial losses that are felt by consumers such as losses on consumer convenience, security, and safety resulting from the delivery process using only online motorcycle taxi services not with a cold chain system, this can risk damaging the vaccine and not being useful. properly as it functions. The following are some consumer protection arrangements, which are carried out by:

a) Creating a consumer protection system that contains access and information, and guarantees legal certainty for consumers;

b) Protect the interests of consumers in particular and the interests of all business actors in general;

c) Improving the quality of products and services to consumers;

d) Provide legal protection to consumers from various kinds of deceptive and misleading business practices;

e) Integrating the implementation, development, and regulation of consumer protection with other areas of protection.

Legal protection for consumers is one thing that has many benefits for all components of society from all walks of life. This is because with the guarantee of legal certainty through a legal protection provided by the applicable laws and regulations, their rights and interests have been clearly protected by law. So that a just and prosperous community life will be achieved, and apart from all possible problems for consumers and business actors that still often occur. Legal certainty to be able to provide legal protection to consumers, among others, is done by providing education for consumers in order to increase their dignity. As well as business actors who open access to information honestly and openly, relating to conditions and even guarantees for goods and/or services traded to consumers. The attitude of online vaccine sellers (entrepreneurs) who are honest and have high responsibility towards consumers is also very much needed, so that those who feel aggrieved then demand compensation can be fulfilled by business actors. Legal protection for consumers related to the online sale of Infanrix Vaccines in the community is very important. This is because the Infanrix Vaccine purchased online may cause damage to the health of the consumer's body due to handling shipments that are not in accordance with the cold chain system. So to provide protection to consumers, the government's role is needed to prevent the circulation of online sales of Infanrix Vaccines, the provisions regarding the cold chain system are regulated in the Regulation of the Food and Drug 
Supervisory Agency Number 24 of 2021 concerning Supervision of Management of Drugs, Drug Ingredients, Narcotics, Psychotropics and Pharmacy Precursors. A. Guidelines for good management of drugs and medicinal ingredients number 4 (four) regarding delivery, number 4.27 (four points twenty-seven) Namely delivery of cold chain products.In addition, Article 30 paragraph (1) of the UUPK also mentions supervision by the government, namely "supervision of the implementation of consumer protection and the application of the provisions of the legislation is carried out by the government, the community, and nongovernmental consumer protection institutions". Legal protection for consumers against the sale of the Infanrix Vaccine online is to protect the rights of consumers as stated in Article 4 point 1 of the UUPK, namely the right to comfort, security and safety in consuming the product and to protect the rights stated in Article 5 paragraph (2) of the Law. Health is that everyone has the right to obtain safe, quality, and affordable health services. Basically the law has given a number of rights and imposed a number of obligations and prohibitions on business actors in order to create a healthy relationship between online vaccine sellers and consumers, but there are still business actors who have bad intentions to carry out Infanrix Vaccine Sales Activities online. In online sales of Infanrix Vaccines, of course, the reciprocal relationship between consumer rights and obligations of business actors does not only occur between consumers and online Infanrix Vaccine sellers or business actors but also involves e-commerce flatfoam as a forum for online buying and selling activities. which is an extension of business actors. Consumer protection from online sales of Infanrix Vaccines is actually sufficient in terms of completeness of law enforcement. Clear rules enclose and direct consumers to protect online vaccine buying and selling activities that do not comply with cold chain procedures. However, in this online Infanrix Vaccine Sales Activity, it seems that the law enforcement aspect is not the only problem. An issue that is also very important is the role and responsibility of the government in the context of supervision. Consumer protection against the sale of Infanrix Vaccines Online through Flatfoam E-commerce in the community can be carried out by the government by supervising vaccine products circulating in the community where this supervisory task has been regulated in Government Regulation Number 58 of 2001 and UUPK.5 Availability of all forms of health efforts quality, safe, efficient and affordable is the responsibility of the government, including the delivery of vaccines for efforts to improve the health of Indonesian children and toddlers. Regarding drug control and the pharmaceutical industry, this authority has been delegated by the government to a special agency, namely BPOM (Food and Drug Supervisory Agency). and food in accordance with the provisions of the applicable laws and regulations. The task referred to by BPOM is based on the Regulation of the Food and Drug Supervisory Agency Number 24 of 2021, BPOM has the authority to:

a) Preparation of macro national plans in their respective fields;

b) Formulation of policies in their respective fields to support macro development;

c) Determination of information systems in their fields; d) Stipulation of requirements for the use of certain additives for food and stipulation of guidelines for drug and food distribution;

e) Licensing and supervision of drug distribution and supervision pharmaceutical industry;

f) Determination of guidelines for the use of conservation, development and supervision of medicinal plants

The UUPK stipulates that the supervision aspect of the implementation of consumer protection and the application of the provisions of the legislation is carried out by the government, the community, and non-governmental consumer protection institutions. However, the government is the main actor in this context. Supervision by the government is carried out by the minister in the field of trade and/or the relevant technical minister, namely the minister in the health sector. However, with the online circulation of Infanrix Vaccine Sales Activities, it can be said that the government, in this case the Ministry of Health, has been negligent in supervising hospitals and clinics. Likewise, the POM Agency has been negligent in terms of administering vaccines and drugs circulating in the community, or it can be said that the POM Agency has neglected its duties as licensing and supervising drug distribution and supervision of the pharmaceutical industry. The Flatfoam E-commerce party has also been negligent in supervising sellers who are registered in the system because they can carry out illegal buying and selling activities without permission for online Infanrix Vaccine Sales Activities. A strong aspect of Civil Law on consumer protection is the right of consumers to obtain compensation for losses suffered as a result of the use of consumer goods. Compensation for losses suffered by consumers as a result of the use of consumer goods is one of the basic rights of consumers in the Consumer Protection Law. The right to compensation is global in addition to other basic rights. Compensation for losses suffered The consumer essentially functions as:

a) Restoration of rights that have been violated;

b) Recovery for material or immaterial losses that have been suffered;

c) Restoration to original state

Losses experienced by consumers due to defective goods are regulated in the provisions of Article 1367 of the Civil Code, hereinafter referred to as the Civil Code. Losses that can be suffered by consumers as a result of the use of these consumer goods can be classified into:

a) Material losses, namely in the form of losses on the goods purchased;

b) Immaterial losses, namely losses that endanger health and/or the soul of the consumer.

Health is important for a country because health is one of the parameters to measure the success of human development. Without human health, it will not be productive to live economically decently and undergo a good education. Regulations and procedures related to the circulation of vaccines have been regulated by the Indonesian government through several laws and Regulations of the Drug Supervisory Agency Number 6 of 2020 concerning Amendments to the Regulations of the Supervisory Agency Drugs and Food Number 9 concerning Technical Guidelines for proper distribution of drugs, Regulation of the Food and 
Drug Supervisory Agency Number 24 of 2021 concerning Supervision of Management of Drugs, Drug Ingredients, Narcotics, Psychotropics and Pharmacy Precursors in Pharmaceutical Service Facilities, Law Number 19 of 2016 concerning Amendments to Law Number 11 of 2008 concerning Information and Electronic Transactions; Government Regulation of the Republic of Indonesia Number 71 of 2019 concerning the Implementation of Electronic Systems and Transactions and Law Number 8 of 1999 concerning Consumer Protection. The government's leading sector is the Ministry of Health as the regulator and BPOM as the operator. In addition, there are still several regulations at the level of a Government Regulation (PP), a Minister of Health Regulation (Permenkes) and also a Regulation of the Head of the POM Agency. Some of these regulations aim to regulate drugs and vaccines used for health services in order to ensure their availability, safety and quality in order to achieve the highest degree of public health. Based on the provisions of non-doctrinal legal theory and law enforcement theory used in research, it is related to consumer protection for online vaccine sales, namely: According to Utrecht, legal certainty has two meanings, namely, first, there are general rules that make individuals know what actions are permissible. or not to do, and secondly, in the form of legal security for individuals from government arbitrariness because with the existence of general rules, individuals can know what the state may charge or do to individuals. This legal certainty comes from the juridical-dogmatic teaching which is based on the positivism school of thought in the legal world which tends to see the law as something that is autonomous and independent, because for adherents of this school, the goal of law is nothing but guaranteeing the realization of a general law. The general nature of a law proves that the law does not aim to achieve justice or benefit, but solely for certainty. The principle of legal certainty mandates that both business actors and business actors obey the law and obtain justice in the implementation of consumer protection and the State guarantees legal certainty. Jan M. Otto as quoted by Sidharta (2006: 85), namely that legal certainty in certain situations implies the following:

a) There are clear or clear, consistent and accessible legal rules issued by the state power;

b) That the authorities (government) agencies apply the legal rules consistently and are also subject to and obedient to them;

c) Whereas the majority of citizens agree in principle with the content and therefore adjust their behavior towards these regulations;

d) That the independent and impartial judges (judicials) apply these legal rules consistently when they resolve legal disputes; and

e) That judicial decisions are concretely implemented.

Normative Legal Certainty is when a regulation is made and promulgated with certainty because it regulates in a definite and logical manner. According to "The International Commission of Jurists" the principles that are considered important characteristics of the state must be subject to law, the government respects the rights of individuals, and an independent and impartial judiciary. According to the author, he agrees that legal certainty is very closely related to justice. According to Sudikno Mertokusumo, legal certainty is a guarantee that the law is carried out, that those entitled by law can obtain their rights and that decisions can be implemented. The creation of legal certainty in statutory regulations requires requirements relating to the internal structure of the legal norm itself. From this explanation, the problem with Online Sales of Infanrix Vaccines through Flatfoam E-commerce in this research is very detrimental to consumers so that legal certainty is needed, namely clarity, does not cause multiple interpretations, does not cause contradictions, and can be implemented. The law must apply firmly in society, contain openness. Without legal certainty, the law will lose its essence, and cause it cannot be used as a law as a guide for human behavior. Based on the provisions of non-doctrinal legal theory and law enforcement theory used in the research research on the linkage with online vaccine sales in the future, namely: The words just and justice are closely related to the notion of equality and equality. , balance and balance (equilibrium), reasonable and reasonable (proportional), balanced or balanced (balance), comparable and comparable In law enforcement if the tools used are not correct then the result must be wrong. Therefore, law enforcement does not only rely on legal certainty which is pursued but still prioritizes justice and expediency. Etymologically, the word adl means a matter or matter that is in the middle, meaning that a fair attitude means being impartial, impartial or treating one another the same. However, a fair attitude is not neutral but also sided with the truth or what is right. Justice and law are vertical, meaning that justice is upheld by the law, there is no justice that is not based on law and the law is enforced to create justice, not just for the law. Justice and law are not horizontal where law and justice each stand alone with the understanding that the law can be carried out independently without justice or vice versa justice is enforced without being based on law. The punishment given must be able to bring benefits, both for the person being punished and for the community, because the purpose of the law is not to make suffering but to create order and benefit for humans. Several theories about justice were put forward by legal philosophers which will be used as the theoretical basis in the discussion of this research, including Aristotle's Theory of Justice, Plato's Theory of Justice and Jhon Rawls' Theory of Justice. The difference between static and dynamic legal theory depends on which alternative is emphasized - human behavior is governed by norms or norms governing human behavior (ie whether knowledge is directed to legal norms created, enforced or obeyed by human actions or to human actions). creation, application or compliance required by legal norms).According to the first alternative, the object of legal theory is law as a norm that applies in a state of rest. According to the second alternative, the object of legal theory is the process by which laws are created and applied laws that run. What should be noted is that the process itself is regulated by law, because of its very significant peculiarity, the law can regulate its own creation and application. material legislation by courts and government organs. Therefore, the act of law creation and application of law which is a legal process is only considered with legal knowledge if the process embodies the contents of legal norms which means that dynamic theory is also addressed by legal norms, namely the norms governing the creation and the application of law. Legal science shows a normative interpretation of its object only by understanding human 
behavior which is the content of and is determined by legal norms. The science of law explains the legal norms created by acts of human behavior and must be applied and obeyed by these actions; Thus it is explained that the normative relationship between the facts applied by the norms. The sentences used by legal science to describe these norms and their relationship as "rules of law" must be distinguished from legal norms created by legal authorities, which are enforced by them and obeyed by legal subjects. On the other hand, the rule of law (in a descriptive sense) is a hypothetical assessment which states that according to the national or international legal order, based on the requirements set by this order, certain consequences or sanctions imposed by that order must be implemented. Legal norms are not considerations, that is, they are not statements about an object of knowledge. According to its meaning, norms are orders; norms can also be the granting of permission or authority; but it doesn't teach .However, when legal norms are expressed linguistically in words and sentences, they will appear in affirmations that state facts. The meaning of action is not the same as the meaning of the legislation that establishes the law. The distinction between the rule of law (in German; Recht-Satz and legal norms (in German Rechts-Norm) expresses the different functions of legal knowledge and the overall function of legal authority, must create law so that it can subsequently be known and explained by legal science. It is true that organs that apply the science of law must also know how the law should be applied. Legislators who apply the constitution must know the law. In the analysis of legal thought we can prove the application of a principle in the rule of law (a sentence used in legal science to explain its object, namely the law that contradicts with a legal norm which is a stipulation) which actually runs on the principle of causality, has the characteristics of a difference from it. In general, under conditions determined by the legal order, a forced act determined by the legal order must be carried out. This is a basic form of the rule of law, such aslaws and regulations, and legal rules that link two elements or two elements. Monitoring the temperature of the infantrix vaccine storage is very important in determining quickly whether the vaccine is still suitable for use or not. The existence of various tools with very sensitive indicators such as Thermometer, Vaccine Vial Monitor (VVM), Freeze-tag is very helpful in monitoring the storage temperature and delivery of vaccines. Sales with an online system for the Infanrix vaccine are possible there are some risks of the immunization program not succeeding so that online sales can ensure delivery with the vaccine chain system (cold chain) to the Vaccine Recipient in order to be able to maintain and guarantee the quality of the vaccines given. Sellers are expected to ensure that with a vaccine chain with good quality standards, the quality of the vaccines given will be maintained. The vaccine chain or cold chain consists of refrigerators and freezes to store vaccines, and flasks (vaccine carriers) to bring vaccines to immunization services, especially for activities outside the building/field. Sales of Infanrix Vaccines with the online system on Flatfoam e-commerce have been going on for a long time until now, it can be seen from the picture that delivery uses the Gosend \& Grabexpress application, but with delivery through this system there is a big risk that is contrary to the vaccine chain system ( cold chain) and there is no guarantee that the Infanrix vaccines received in the hands of consumers are in good condition, suitable for use and the potential to cause no immunity as shipping stated that "all errors due to the delivery and storage of vaccines afterward are not the responsibility of the seller" The delivery system that carried out by online sellers, it is clear that contrary to the Minister of Health Regulation Number 12 of 2017 concerning the Implementation of Immunization, it is stated that vaccines are biological products that are easily damaged so they must be stored at a certain temperature, namely at a temperature of 2 to $8^{\circ} \mathrm{C}$ for frozen sensitive vaccines (not frozen), and at a temperature of -15 to $-25 \mathrm{C}$ for heat sensitive vaccines where vaccine storage requires special attention because vaccines are biological preparations that are susceptible to changes in environmental temperature. Chillers and freezers used must be designed for the purpose of storing cold chain products and capable of maintaining the required temperature. A calibrated thermometer is placed at the most accurate and representative point, this is needed to continuously monitor the temperature during operation. The temperature point that is accurate and representative of the entire storage area is determined by mapping the critical point temperature. The temperature in the cold chain product storage is monitored at least 3 (three) times a day and an alarm is provided to indicate if a temperature deviation occurs. The alarm setting for vaccine storage is recommended at a temperature of $2.5-7.5^{\circ} \mathrm{C}$, for vaccine storage $2-8{ }^{\circ} \mathrm{C}$, the alarm must be checked periodically to ensure the alarm is functioning properly (BPOM, 2015). The vaccine cold chain is a procedure to keep the vaccine at a certain temperature that has been set so that it still has good potential from the manufacture of the vaccine to the time of its administration (injected or dripped) to the target. Cold chain products have a short shelf life, complex storage, handling and distribution systems with multiple requirements, high shipping costs and the need for a controlled cold environment temperature. Pharmaceutical wholesalers (PBF) who have a license to distribute vaccines with a cold chain system by distributing cold chain products must be able to ensure that the product temperature can be maintained during the process of receiving, storing and shipping to the hands of users to avoid unwanted risks. The procedure for receiving the product from the principal must comply with the requirements for Good Drug Distribution Practices. PBF must check: product name, product physical condition, product quantity, expiry date, batch number, condition of temperature monitoring equipment and condition of Vaccine Vial Monitor (VVM) (especially for vaccines that have been equipped with VVM). According to CDOB (BPOM, 2012) there are two storage temperatures at pharmaceutical wholesalers $(\mathrm{PBF})$ facilities, namely:

1) Chiller or cold room ( $2 \mathrm{oC}$ to $8 \mathrm{oC})$, for storing vaccines and serum with a storage temperature of $2 \mathrm{oC}$ to $8 \mathrm{oC}$, usually used for storing measles, BCG, DPT, TT, DT, Hepatitis B, DPT-HB vaccines .

2) Freezer or freezer room (temperature $-15 \mathrm{oc} \mathrm{s} / \mathrm{d}-25 \mathrm{oc}$ ) to store frozen products for example polio vaccine.

Supervision of the circulation of drugs and vaccines is aimed at ensuring that drugs and vaccines circulating in the community meet the quality, safety and efficacy requirements. This supervision process has been regulated by the Regulation of the Food and Drug Supervisory Agency 
Number 24 of 2021 concerning Supervision of Management of Drugs, Drug Ingredients, Narcotics, Psychotropics Drug circulation including vaccines is carried out by the government by appointing the Minister of Health together with BPOM (investigation division) as executor. The government carries out the development, supervision and control of drugs, while business actors in the drug sector are responsible for the quality of drugs in accordance with their business functions. The duties of supervision and control which are the responsibility of the government are carried out professionally, responsibly, independently and transparently. BPOM conducts continuous monitoring of vaccines starting from pre-market to post-market evaluations. Pre-market evaluation is carried out by ensuring compliance with safety, efficacy and quality requirements, as well as testing to issue lot/batch releases before the product is marketed. Post-market supervision is carried out through sampling and testing of circulating products in both distribution facilities and health service facilities, as well as supervision at production facilities to ensure the implementation of Good Manufacturing Practices of Drugs (GMP) and supervision at distribution facilities to ensure the implementation of Good Drug Distribution Methods ( CDOB) including ensuring the existence of a cold chain throughout the distribution chain. Vaccine supervision due to online vaccine buying and selling activities, BPOM has taken anticipatory steps towards Online Sales of Infanrix Vaccines through Flatfoam E-commerce BPOM has taken several actions:

a) Checking and tracing the possibility of spreading Infanrix Vaccine Sales Online through Flatfoam Ecommerce;

b) If you find a vaccine that is not from an official distribution facility or is suspected of being an Online Sales of Infanrix Vaccine through Flatfoam E-commerce, you are asked to take precautions, until confirmation of the test results is obtained;

c) Evaluating the distribution system and the source of the products it distributes;

d) Actively coordinates with the Indonesian Ministry of Health to minimize the impact of the spread and circulation of Infanrix Vaccine Sales Online through the Flatfoam E-commerce.

Chapter IV of the Health Law discusses several regulations that address government responsibilities, namely:

Article 14

1) The government is responsible for planning, regulating, organizing, fostering, and supervising the implementation of health efforts that are evenly distributed and affordable by the community.

2) The responsibility of the Government as referred to in paragraph (1) is devoted to public services.

a) Article 15: The government is responsible for the availability of the environment, arrangement, health facilities, both physical and social for the community to achieve the highest degree of health.

b) Article 16: The government is responsible for the availability of resources in the health sector that is fair and equitable for the entire community to obtain the highest degree of health.

c) Article 17: The government is responsible for the availability of access to information, education, and health service facilities to improve and maintain the highest level of health.

d) Article 18: The government is responsible for empowering and encouraging the active role of the community in all forms of Health efforts.

e) Article 19: The government is responsible for the availability of all forms of quality, safe, efficient and affordable health efforts.

f) Article 20 (1) The government is responsible for the implementation of public health insurance through the national social security system for individual health efforts.

The vaccine quality control process is carried out very strictly, consistently and periodically. Randomly selected vaccines to be checked for quality. The indicators examined are sterility, chemical stability, safety or toxicity, virulence, and even its effect on the surrounding environment. One of the other important things is the implementation of lot test or batch release. For each series of vaccine products at a certain time, marking is carried out in the form of a certain code such as lot or batch number to ensure the consistency of purity, potency and safety of vaccines produced at different times remains the same and there are no deviations. In ensuring the safety, quality and efficacy of vaccine products, a clinical trial stage (CT-clinical trial) is carried out which is divided into three stages. Clinical trial I to determine product safety and side effects. Phase II clinical trials to determine and evaluate the immune response and Phase III clinical trials to determine the level of efficacy (efficacy) of vaccines with predetermined subjects. Article 1 point 7 of the Regulation of the Minister of Health of the Republic of Indonesia Number 12 of 2017 concerning the Implementation of Immunization states that the Cold Chain or in other terms, namely the cold chain is a vaccine management system intended to maintain and guarantee the quality of vaccines in distribution starting from the vaccine manufacturer, delivery to delivery. target. To maintain quality, vaccines must be stored in a place with a certain temperature control. The vaccine cold chain is a temperature controlled environment used to maintain and distribute vaccines under optimal conditions. The vaccine cold chain relies on three key elements: effectively trained personnel, proper transport and storage equipment, and efficient management procedures. All three elements must remain consistent to ensure vaccines are transported and stored properly. Cold Chain equipment consists of cold boxes, vaccine carriers, cool packs, cold packs, thermometers, thermographs, freezing temperature monitoring devices, continuous temperature monitoring or recording devices, alarms, and special refrigerated vehicles. Cold Chain supporting equipment includes Automatic Voltage Stabilizer (AVS) and standby generator. There are weaknesses and opportunities in the supervision of health facilities, so the presence of online buying and selling activities for Infanrix Vaccines Online through Flatfoam E-commerce. The circulation of Infanrix Vaccine Sales Online through Flatfoam E-commerce, has violated the rights of consumers or patients to obtain safe, efficacious, and quality vaccines so that it can result in the proper function of the vaccine being perfect and therefore not good in the delivery system. Public accountability, namely sellers/distributors in online buying and selling activities of Infanrix Vaccines Online 
through Flatfoam E-commerce, as business actors have the duty and obligation to participate in creating and maintaining a healthy business climate that supports the development of the national economy as a whole. Therefore, to producers, distributors, sellers, business actors are charged with the responsibility for the implementation of these duties and obligations, namely through the application of legal norms, propriety, and upholding the prevailing customs in the business world. Business ethics is one of the guidelines for every development of the national economy as a whole. The principle of business is business, cannot be applied, but must be with an understanding of business principles for development. Therefore, producers, distributors, sellers or business actors must work hard to make their business contribute to the improvement of overall national development. The responsibility of a business actor for the seller of a product of goods and/or services is very necessary, so that the rights that should be accepted by consumers can be fulfilled. With such ways and attitudes of business actors, the problems of consumer protection that still occur can be minimized and even resolved because consumers and online vaccine sellers have understood their respective rights and obligations. Civil liability, namely what is meant in Article 19 of the UUPK is that if a consumer suffers a loss in the form of damage, pollution, or financial and health losses due to consuming the product being traded, as a business actor, it is obligatory to provide compensation, either in the form of a refund, replacement of goods, care, as well as by providing compensation. As stated by Stern and Eovaldi in the United States, the issue of liability in connection with the consequences of a defective product can be put into two different legal categories, namely into a breach of contract and/or into a problem of tort, each with its own specialty. . Qualification of events that cause harm to consumers, namely:

a) Acts that harm consumers as an act of default; Searching and discovering whether or not there is a contractual relationship between an online vaccine seller and a consumer is sometimes not easy. If it turns out that there is an agreement or contract, even in a simple form between an online vaccine seller and a consumer, it can easily be concluded that they are contractually bound. However, in reality this is not always the case. So the next step is to find or collect facts about the event that caused the loss and then reconstruct it into a contract or agreement. In order to be entered into an agreement or contract, the minimum conditions of the contract as regulated in Article 1320 of the Civil Code must be met.

b) Acts that harm consumers as an unlawful act in relation to consumer protection, in particular determining the responsibility of online vaccine sellers to consumers who suffer losses due to defective products during the delivery process via online gojek, then the facts surrounding the event that caused the loss are first qualified to be an act against the law. This means that it must be shown that the actions of the online vaccine seller or business actor are unlawful acts, whether it be a violation of consumer rights, or the online vaccine seller has committed an act that is contrary to his own legal obligations, violated decency, or has done something illegal. contrary to propriety in the social life of the community in carrying out their business, especially propriety in terms of shipping and distributing their products. The behavior of business actors in Selling Infanrix Vaccines Online through Flatfoam E-commerce is clearly an act against the law.

Formally it has violated the provisions of the Health Law and UUPK. Thus, business actors in Online Sales of Infanrix Vaccines through Flatfoam E-commerce have committed acts against the law, both formally and materially. Article 1365 of the Civil Code stipulates that every unlawful act, which causes harm to another person, obliges the person who due to his/her fault published the loss, to compensate for the loss. Furthermore, Article 1367 of the Civil Code states that everyone is responsible not only for losses caused by his own actions, but also for losses caused by the actions of people who are his responsibility or caused by goods under his control. Based on Article 17 paragraph (1) of the Regulation of the Minister of Health Number 42 of 2013 concerning the Implementation of Immunization, it is stated that the government is responsible for the distribution of logistics in the form of vaccines, Auto Disable Syringes, safety boxes and documents for recording immunization status for the implementation of mandatory immunization to the provinces. So the procurement of vaccines to distribution is the responsibility of the government. The central and local governments are responsible for the procurement of vaccines, from buying from pharmaceutical companies and distributing them. If the consumer has suffered a loss due to the Online Sales of Infanrix Vaccines through Flatfoam Ecommerce, it is in accordance with the UUPK which accommodates the principle of responsibility (product liability). Online via Flatfoam E-commerce is sent via online gojek to consumers causing losses because it is possible to have defects at the time of delivery. In addition to adhering to the principle of product liability, UUPK also adheres to semi-absolute liability (strict liability). UUPK uses the principle of semi strict liability regulated in Article 19 of the UUPK, business actors are responsible for providing compensation for consumer damage or loss. The principle of responsibility in consumer protection law is generally used to "ensnare" business actors, especially sellers of goods that market their wares that have harmed consumers. This principle of responsibility is known as product liability. According to this principle, online vaccine sellers must be responsible for losses suffered by consumers from using products sold and bought online. absolute responsibility or strict liability, namely the element of error does not need to be proven by the plaintiff as the basis for compensation, this provision is a lex specialis in lawsuits regarding unlawful acts in general. However, the plaintiff or consumer is still given the burden of proof, although not as big as the defendant. In this case, the consumer only needs to prove the existence of a causal relationship between the actions of the business actor and the losses he suffers. The rest can be used the principle of absolute responsibility (strict liability). With the implementation of this absolute responsibility principle, every consumer who feels aggrieved due to defective or unsafe products or goods can claim compensation without having to question whether or not there is an element of error on the part of the business actor. In the UUPK there are three articles that describe the product responsibility system in consumer protection law in Indonesia, namely the provisions of Article 19, Article 23, and Article 28 of the 
UUPK. Article 19 of the UUPK formulates the responsibilities of online vaccine sellers as follows:

1) Business actors are responsible for providing compensation for damage, pollution and/or consumer losses due to consuming goods and/or services produced or traded;

2) The compensation as referred to in paragraph (1) may be in the form of a refund or replacement of goods and/or services of a similar or equivalent value, or health care and/or the provision of compensation in accordance with the provisions of the applicable laws and regulations;

3) Payment of compensation is carried out within a grace period of seven days after the date of the transaction;

4) The provision of compensation as referred to in paragraphs (1) and (2) does not eliminate the possibility of criminal prosecution based on further evidence regarding the existence of an element of error;

5) The provisions as referred to in paragraph (1) and paragraph (2) shall not apply if the business actor can prove that the error is the fault of the consumer.

It's just that the compensation is carried out within a grace period of 7 (seven) days after the date of the transaction. Of course, this is difficult to do in Online Sales of Infanrix Vaccines through Flatfoam E-commerce after a long time the transaction has been carried out, even though the provision of compensation does not completely eliminate the possibility of criminal prosecution based on further evidence regarding the element of error. The provisions of Article 19 were later developed in Article 23 which states: "Business actors who refuse and/or respond and/or do not fulfill compensation for consumer demands as referred to in Article 19 paragraph (1), paragraph (2), paragraph (3), and paragraph (4) can be sued through the Consumer Dispute Settlement Agency (BPSK) or file a lawsuit with the judiciary at the consumer's domicile." The formulation of Article 23 UUPK appears to be based on a framework of thought, namely first that Article 19 UUPK adheres to the principle of presumption of negligence. This principle is based on the assumption that if the business actor does not make a mistake, the consumer will not suffer a loss, meaning that if the business actor has made a mistake, the consumer will suffer a loss. Based on the provisions of nondoctrinal legal theory and law enforcement theory used in the research research, the relationship with online vaccine sales in the future, namely the difference between static and dynamic legal theory depends on which alternative is emphasized - human behavior regulated by norms or norms. norms governing human behavior (ie whether knowledge is directed to legal norms created, enforced or obeyed by human acts or to acts of creation, application or compliance required by legal norms). According to the first alternative, the object of legal theory is law as a norm that applies in a state of rest. According to the second alternative, the object of legal theory is the process by which laws are created and applied laws that run. What should be noted is that the process itself is regulated by law, because of its very significant peculiarity, the law can regulate its own creation and application. The creation of general legal norms or the process of drafting laws are regulated by the constitution, formal or procedural laws governing material laws by courts and government organs. Therefore, the act of law creation and application of law which is a legal process is only considered with legal knowledge if the process embodies the contents of legal norms which means that dynamic theory is also addressed by legal norms, namely the norms governing the creation and application of law. Legal science shows a normative interpretation of its object only by understanding human behavior which is the content of and determined by legal norms. The science of law explains the legal norms created by acts of human behavior and must be applied and obeyed by these actions; Thus it is explained that the normative relationship between the facts is applied by the norms. The sentences used by legal science to describe these norms and their relationship as "rules of law" must be distinguished from legal norms created by legal authorities, which are enforced by them and obeyed by legal subjects. On the other hand, the rule of law (in a descriptive sense) is a hypothetical assessment which states that according to the national or international legal order, based on the requirements set by this order, certain consequences or sanctions imposed by that order must be implemented. Legal norms are not considerations, that is, they are not statements about an object of knowledge. According to its meaning, norms are orders; norms can also be the granting of permission or authority; but he does not teach. However, when legal norms are expressed linguistically in words and sentences, they will appear in affirmations that state facts. The meaning of action is not the same as the meaning of the legislation that establishes the law. The distinction between the rule of law (in German; Recht-Satz and legal norms (in German Rechts-Norm) reveals the different functions of legal knowledge and the overall function of legal authority, must create law so that it can subsequently be known and explained by legal science. It is true that organs that apply the science of law must also know how the law should be applied. Legislators who apply the constitution must know the law. with legal norms which are stipulations) which actually run with the principle of causality, have the characteristics of differences from it. In general, under the conditions stipulated by the legal order, an act of coercion determined by the legal order must then be carried out. This is the basic form of the rule of law, such as statutory law, and the rule of law that links two elements or two elements. The author is of the opinion that the formulation of Article 23 of the UUPK shows that the principle of responsibility which is also embraced in the UUPK is the presumption of being responsible. This principle is a modification of the principle of liability based on error with the burden of proof reversed. Therefore, the authors conclude that the UUPK as a whole adheres to the principle of responsibility based on errors with two modifications. First, the principle of responsibility based on the presumption of guilt or negligence or the business actor is already considered guilty, so there is no need to prove his guilt. And second is the principle of always being responsible with the burden of proof reversed. It is clear that such a legal construction illustrates the progress of the previous system of responsibility, but has not fully adhered to the principle of absolute responsibility as explicitly formulated in several positive laws in other countries. This is also reflected in the final opinion when giving approval to the Draft on Consumer Protection which states: "In this Law, an article is included which allows for reverse evidence both in terms of our country's law in the reform era. the principle of responsibility based on fault, a step behind the principle of 
absolute responsibility. The availability of all forms of quality, safe, efficient, and affordable health efforts is the responsibility of the government, including the availability of vaccines for efforts to improve the health of children and toddlers in Indonesia. Furthermore, related to drug control and the pharmaceutical industry, the government has delegated this authority to a special agency, namely BPOM (Food and Drug Supervisory Agency). In Chapter IV Articles 14 to 20 of the Health Law, it is regulated about the responsibility of the government in various aspects of health so that all people can obtain the highest degree of health. The government has responsibility for availability of environment, arrangement, health facilities, both physical and social;

a) Availability of resources in the health sector that is fair and equitable for;

b) Availability of access to information, education, and health service facilities;

c) Empowerment by encouraging the active role of the community in all forms of health efforts;

d) The availability of all forms of quality, safe, efficient and affordable health efforts.

e) Implementation of public health insurance through the national social security system for individual health efforts.

The business actor has violated Article 197 Jo. Article 106 paragraph (1) of the Health Law, namely pharmaceutical preparations and medical devices can only be circulated after obtaining a distribution permit with the following elements;

1) Everyone;

2) On purpose;

3) Produce or distribute pharmaceutical preparations and/or medical devices that do not have a distribution permit as referred to in Article 106 paragraph (1) of the Health Law;

4) Those who do, order to do and those who participate in doing.

The element of everyone, that what is meant by everyone in this case is every legal subject or anyone, male or female who can be held accountable, who is brought to trial because of a crime and unlawful act that he is accused of. Whereas based on what has been described as mentioned above, Element intentionally, that according to Legal Science there are three forms of intentionality as follows:

1) Intentional as an intention (opzet als oogmerk); Deliberation as an intention is intentional to achieve a goal. That is, between the motivation of someone who does the deed, the action, and the result is actually realized. A person's motivation greatly influences his actions.

2) Intentional with conscious certainty (opzet met zekerheidsbewustzijn or noodzakkelijkheidbewustzijn); In contrast to intentional as an intention, intentiona.

3) as certainty or necessity is intentional which has two consequences. The first effect is desired by the perpetrator, while the second effect is not desired but must or must occur.

4) Deliberately conscious of the possibility (dolus eventualis or voorwaardelijkopzet).
Sometimes it is intentional to cause consequences that are not certain to occur but are a possibility. In this case, there is an intentional act with awareness of the magnitude of the possibility or opzet met waarschijnlijkheidsbewustzijn. Dolus eventualis is born. In Selling Infanrix Vaccines Online through Flatfoam E-commerce online sellers have violated Article 4 point 1 UUPK, namely the right of consumers to get the right to comfort, security, and safety in consuming goods and/or services, business actors have also violated Article 8 paragraph (1) letter a UUPK, which is an act that is prohibited for online sellers in which online sellers are prohibited from trading/sending goods and/or services that do not meet or do not comply with the required standards and statutory provisions.

\section{Conclusion}

Based on the discussion regarding Infanrix Vaccine Sales Online through Flatfoam E-commerce, the following conclusions can be drawn:

1) Online buying and selling activities of Infanrix Vaccines Online through Flatfoam E-commerce resulted in the position of consumers and business actors becoming unbalanced and consumers being in a weak position. Consumers were used as objects of business activity by business actors in order to obtain the maximum profit. The main factor that becomes the weakness of consumers is the level of consumer awareness of their rights is still low. Business actors or online sellers have an obligation to deliver goods or services as best and as safe as possible and try to provide satisfaction to consumers. Providing correct information about a product is also very important. This will relate to security, health and consumer safety issues. The purpose of consumer protection is so that people do not consume or use goods and or services that can endanger safety, health and so on, so that people feel safe and obtain satisfaction and benefit from the products purchased. In Law Number 8 of 1999 concerning Consumer Protection, hereinafter referred to as UUPK, it has been stated explicitly in a clause concerning the responsibilities that must be given by business actors to consumers. In UUPK Article 19 paragraph (1) it is stated that "Business actors are responsible for providing compensation for damage, pollution, and/or consumer losses due to consuming goods and/or services produced or traded." In Article 2 of the UUPK, it is stated that legal protection for consumers is carried out as a joint effort based on five principles in national development, namely the principle of benefit, the principle of justice, the principle of balance, the principle of security and safety, and the principle of legal certainty. The purpose of the planned implementation, development and regulation of legal protection for consumers is to increase the dignity and awareness of consumers, and indirectly encourage business actors to carry out business activities with a full sense of responsibility. Business actors realize that they must respect consumer rights, produce quality goods and services, safe to use, follow applicable standards, at reasonable prices. Legal protection for consumers related to the online sale of Infanrix Vaccines in the community is very important. This is because the Infanrix Vaccine purchased online may cause damage to the health of the 
consumer's body due to handling shipments that are not in accordance with the cold chain system. So to provide protection to consumers, the government's role is needed to prevent the circulation of online sales of Infanrix Vaccines, the provisions regarding the cold chain system are regulated in the Regulation of the Food and Drug Supervisory Agency Number 24 of 2021 concerning Supervision of Management of Drugs, Drug Ingredients, Narcotics, Psychotropics and Pharmacy Precursors. A. Guidelines for good management of drugs and medicinal ingredients number 4 (four) regarding delivery, number 4.27 (four points twenty-seven) Namely delivery of cold chain products. In addition, Article 30 paragraph (1) of the UUPK also mentions supervision by the government, namely "supervision of the implementation of consumer protection and the application of the provisions of the legislation is carried out by the government, the community, and non-governmental consumer protection institutions".

2) Monitoring the storage temperature of infanrix vaccine is very important in determining quickly whether the vaccine is still suitable for use or not. The existence of various tools with very sensitive indicators such as Thermometer, Vaccine Vial Monitor (VVM), Freeze-tag is very helpful in monitoring the storage temperature and delivery of vaccines. Sales with an online system for the Infanrix vaccine are possible there are some risks of the immunization program not succeeding so that online sales can ensure delivery with the vaccine chain system (cold chain) to the Vaccine Recipient in order to be able to maintain and guarantee the quality of the vaccines given. Sellers are expected to ensure that with a vaccine chain with good quality standards, the quality of the vaccines given will be maintained. The vaccine chain or cold chain consists of a refrigerator and freeze to store vaccines, and a flask (vaccine carrier) to carry vaccines. The vaccine cold chain is a procedure to keep the vaccine at a certain temperature that has been set so that it still has good potential from the manufacture of the vaccine to the time of its administration (injected or dripped) to the target. The procedure for receiving the product from the principal must comply with the requirements for Good Drug Distribution Practices. PBF must check: product name, product physical condition, product quantity, expiry date, batch number, condition of temperature monitoring equipment and condition of Vaccine Vial Monitor (VVM) (especially for vaccines that have been equipped with VVM). According to CDOB (BPOM, 2012) there are two storage temperatures in pharmaceutical wholesalers (PBF) facilities. Regulation of the Food and Drug Supervisory Agency Number 24 of 2021 concerning Supervision of the Management of Drugs, Drug Ingredients, Narcotics, and Drug Distribution Psychotropics. BPOM conducts continuous monitoring of vaccines starting from premarket to post-market evaluations. Pre-market evaluation is carried out by ensuring compliance with safety, efficacy and quality requirements, as well as testing to issue lot/batch releases before the product is marketed. Post-market supervision is carried out through sampling and testing of circulating products in both distribution facilities and health service facilities, as well as supervision at production facilities to ensure the implementation of Good Manufacturing Practices of Drugs (GMP) and supervision at distribution facilities to ensure the implementation of Good Drug Distribution Methods ( CDOB) including ensuring the existence of a cold chain throughout the distribution chain. The government is responsible for planning, regulating, organizing, fostering, and supervising the implementation of health efforts that are equitable and affordable by the community. The circulation of Infanrix Vaccine Sales Online through Flatfoam E-commerce, has violated the rights of consumers or patients to obtain safe, efficacious, and quality vaccines so that it can result in the function of the vaccine being perfect and therefore not good in the delivery system

Based on the conclusions above have some suggestions as follows:

1) There is a need for more detailed regulations regarding consumer protection in the health sector, because consumer protection arrangements are in the health sector. This is intended so that the role of consumer or patient rights in the health sector can be carried out, namely in legal protection for consumers and business actors.

2) Delivery of vaccines with online purchases cannot guarantee the benefits of the vaccine. limited facilities at the time of delivery with Infanrix Vaccine Sales Online required a good system at the time of delivery Freeze-tag is very helpful in monitoring the storage temperature and delivery of vaccines and cold chain product packaging must be put in a cool box and added an ice pack. The cool box is then inserted into the vehicle. The number of ice packs needed varies based on the distance and length of the delivery process. The temperature at the time of delivery is also monitored using a data logger or EDLM (Electronic Data Logging Monitors).

\section{References}

[1] Abdul Aziz Dahlan, et al. (editor), Encyclopedia of Islamic Law, (Jakarta Ikhtiar Baru Van Hoeve, 1997).

[2] Amran Suadi, Philosophy of Law - Reflections on Pancasila Philosophy, Human Rights and Ethics, (Jakarta; Prenadamedia Group, 2019).

[3] Barder Johan Nasution, Legal Research Methods, (Mandar Maju, Bandung: 2009).

[4] Barkatullah, Abdul Halim. 2008. Consumer Protection Law. Bandung: Nusa Media

[5] Bernard L, Tanya, Yoan N Simanjuntak, Markus Y. Hage, "Legal Theory, Orderly Strategies of Man Across Spaces and Generations", (Jakarta - Genta Publishing).

[6] Cst Kansil, Dictionary of Legal Terms, Gramedia Pustaka, Jakarta, 2009.

[7] Indonesian Ministry of Health. Vaccine Management and Vaccine Chain Training at Puskesmas Level. Indonesian Ministry of Health. 2009.

[8] Ministry of Health of the Republic of Indonesia .Guidelines for Vaccine Management; Jakarta 2009.

[9] Directorate General of PPM \& PL Ministry of Health RI, Technical Guidelines for Vaccines and Cold Chain, 
2002.Fernando M Manulang, 2007, Hukum Dalam Kepastian, Prakarsa, Bandung.

[10] Hans Kelsen, Pure Legal Theory, (Bandung: Nusa Media 2018).

[11] Jimly Asshiddiqie, Idea of the Indonesian State of Law, National Legal Midwifery Agency, National Law Magazine, 2011.

[12] Jimly Asshidiqie, Social Justice Constitution, (Kompas, Jakarta, 2018).

[13] Ministry of Health of the Republic of Indonesia; Directorate General of Disease Control and Environmental Health; Immunization Officer Cold Chain Management Guidelines; Jakarta; 2013.

[14] Matthias DM, Robertson J, Garrison MM, Newland S, Nelson C. Freezing temperatures in the vaccine cold chain: A systematic literature review. 2007.

[15] Riduan Syahrani, Summary of the Essence of Legal Studies, Citra Aditya, Bandung, 1999.

[16] Rizki Annisa. 2013. Legal Protection for Consumers for Selling Illegal Drugs Online. Faculty of Law Universitas Brawijaya, Journal.

[17] Siswati, Sri. 2013. Ethics and Health Law in the Perspective of Health Law. Jakarta: King Grafindo Persada

[18] Soekanto Soerjono, Influence of Legal Research, (Jakarta.UII Press: 1986).

[19] Soerjono Soekanto \& Sri Mamudji, Normative Legal Research (A Brief Overview), (Jakarta: Rajawali Pers 2001).

[20] Sudikno Mertokusumo, 2007, Knowing the Law is an Introduction, Liberty, Yogyakarta.

[21] Suharsimi Arikunto, Research Procedure: A Practical Approach (Jakarta: Rieneka Cipta, 2002).

[22] Sugeng Istanto, Legal Research, (Yogyakarta; CV. Ganda, 2007).

[23] Sugiyono, Qualitative, Quantitative, and R\&D Research Methods, (Bandung: Alfabeta 2005).

[24] Suteki, Galang Taufani, "Legal Research Methodology (Philosophy, Theory and Practice)", (Depok: PT RajaGrafindo Persada 2018).

[25] Tata Wijayanta, Principles of Legal Certainty, justice and expediency in relation to commercial court bankruptcy decisions, Journal of Legal Dynamics, Vol. 12.

[26] Zainudin Ali, Legal Research Methods, (Jakarta: Sinar Graphic 2010).Undang-undang Nomor 8 Tahun 1999 tentang Perlindungan Konsumen.

[27] Law Number 11 of 2008 concerning Information and Electronic Transactions.

[28] Law No. 36 of 2009 concerning Health.

[29] Regulation of the Minister of Health of the Republic of Indonesia Number 12 of 2017 concerning the Implementation of Immunization

[30] Regulation of the Head of the Food and Drug Supervisory Agency of the Republic of Indonesia Number 25 of 2017 concerning Good Drug Distribution Methods (CDOB).

[31] Regulation of the Head of the Food and Drug Supervisory Agency of the Republic of Indonesia Number 6 of 2020 concerning Amendments to Regulation of the Food and Drug Supervisory Agency Number 9 of 2019 concerning Technical Guidelines for Good Drug Distribution Methods (CDOB).
[32] Regulation of the Food and Drug Supervisory Agency Number 8 of 2020 concerning Control of Drugs and Food Circulated Online.

[33] KOMPAS.com, https://lifestyle.kompas.com/read/2016/07/18/1110700 923/Ini.Bedanya. Vaccine.with.SideEffect.Fever.and.No, 2016.

[34] Mulya Nurbilkis, BPOM: 302 Internet Sites Selling Counterfeit Drugs, http://news.detik.com/read/2014/05/26/164027/259273 2/10/bpom-302-sites-internetmenjual-falsu, DetikNews, 2014.

[35] Practical Guide to Healthcare-BPJS Immunization Services, https://bpjskesehatan.go.id/bpjs/dmdocuments/0f5f2e7209f8d40f6 88564599a138a09.pdf.

[36] No Need for This Cost Free Immunization List from the Government,https://www.popmama.com/baby/0-6months/faela-shafa/ini-dia-List-immunization-gratisdari-government, June2020. 